\title{
Words omitted and to be inserted.
}

\author{
Bed-vow, marriage-vow: Sonn. 152, 3. \\ Blunt -witted, rude and insensible: IIGB III, \\ Curer, a henler, a physician: Wiv. II, 3, 40. \\ Troil. V, 1, 55. cf. Body-curer and Soul-curer. \\ Doughy, unbaked, unripe : whose villanous saffion \\ would have made all the unbaked and doughy youth of \\ a nation in his colour, All's IV, 5, 3. \\ Flute, a sort of wind-instrument : Ant. II, 2,200. \\ II, 7. 138 . \\ Name in Mids. I, 2, 44. 58. IV, 1, 207. \\ Indian-like, like an Indian: All's I, 3, \\ 210. \\ Indistinguished, reading of $\mathrm{Ff}$ in $\mathrm{Lr}$. IV, 6, \\ 278; Qq undistinguisled, q. v. \\ Onj $x$, a sort of gem; reading of Qq in Hml. $Y$, \\ 2, 283; Ff union. \\ Quid for que, changed by a sad mistake to Quid \\ pro quo. \\ she-knight-errant, which should be between \\ Shekels and She-lamb, is wrongly placed after She- \\ Mercury.
} 2, 210. 
